\title{
Influence of commercial refining on some quality attributes of sunflower oil
}

\section{Syed Nasrullah Shah ${ }^{1}$, Sarfaraz Ahmed Mahesar ${ }^{1}$, Syed Tufail Hussain Sherazi ${ }^{1}$, Muhammad Aamir Panhwar ${ }^{2}$, Shafi Muhammad Nizamani ${ }^{1}$, Aftab Ahmed Kandhro ${ }^{3}$}

\author{
1 - National Centre of Excellence in Analytical Chemistry, University of Sindh, \\ Jamshoro, Pakistan \\ 2 - Mehran University of Engineering and Technology, Jamshoro, Pakistan \\ 3 - Dr. M.A. Kazi Institute of Chemistry, University of Sindh, Jamshoro, Pakistan
}

Keywords:

Sunflower

Oil

Refining

Physiochemical

Properties

Fatty acid

Article history:

Received

12.03.2018

Received in revised

form 30.04.2018

Accepted

29.06.2018

Corresponding

author:

Sarfaraz.Ahmed

Mahesar

E-mail:

sarfaraz.mahesar@

usindh.edu.pk

DOI:

\section{Abstract}

Introduction. The research was carried out to check the impact on the commercial refining of sunflower oil such as crude, neutralization, bleaching and deodorization on some specific physicochemical attributes that are essential for quality point of view and health.

Materials and methods. Sunflower (SFO) oil samples (crude, neutralized, bleached and deodorized) were collected from the processing line unit from industrial oil company. In this study physicochemical parameters of SFO have been determined by official IUPAC and AOCS methods, while fatty acid composition was checked on GC-MS.

Results and discussion. The obtained outcome of physical parameters showed that neutralization, bleaching and deodorization steps of crude SFO considerably decreased the moisture content $(0.46-0.04 \%)$, color $(2.8-1.1 \mathrm{R}, 28.0-11.0 \mathrm{Y})$, freezing point (3.2-2.3) and smoke point (226.0-219.0), while some lesser change in refractive index was also observed. Moreover, in the case of chemical parameters for instance free fatty acids, saponification value and peroxide value were reduced from 0.56 to $0.06 \%, 178.5$ to $177.2 \mathrm{mg} \mathrm{KOH} / \mathrm{g}$ oil and 3.2 to $0.9 \mathrm{mEqO}_{2} / \mathrm{Kg}$ oil, correspondingly. On the other hand refining steps did not showed significant impact on the iodine value (126.0-125.2 $\mathrm{gI}_{2} / 100 \mathrm{~g}$ of oil) and fatty acid composition (total unsaturated fatty acids 89.06-90.91\%). The most important influence during industrial processing was noted in soap contents, as these are generated during second step of refining. In present study soap content were reduced from 121.0 to $30.4 \mathrm{ppm}$ during neutralization to deodorization steps.

Conclusions. Among industrial process, deodorization step has greater influence on physicochemical attributes on the quality and stability of processed SFO.

$10.24263 / 2304-$

974X-2018-7-2-6 


\section{Introduction}

The cultivated sunflower (Helianthus annuus L.) dicotyledonous plant is one among 67 species in the genus Helianthus [1]. It is one of the four most essential annual crops within the global grown for edible oil [2]. Generally, the oil content present in the sunflower seeds ranges from $16-24 \%$ [3]. The world's whole production of sunflower oil is nearly 16 million tonnes annually with Argentina, Ukraine, Russia and China as the largest producers [4]. Sunflower oil contain valuable components such as soluble vitamins (A, D, E and K), phytosterols, natural pigments and phospholipids (1 to 5\%) [5]. This oil plays an essential role in the diet and provides energy [6].

Crude oil obtained from sunflower seed needs refining before the utilization in order to eliminate unwanted compounds (free fatty acids and color pigments). The objective of refining is to take away those impurities with the least possible impact on desirable compounds present in the crude vegetable oils in order to obtain bland, odorless and oxidative stable refined vegetable oils [7] that are acceptable to consumers.

Presence of typical compounds such as waxes, odiferous volatiles, metal traces and pigments impacts negatively on the appearance, taste, smell and storage consistency of the refined oils. These compounds must be eliminated from edible oils to yield a stable product with a pleasant flavor [8]. The presence of phospholipids can cause the oil discoloration, act as a precursor of off-flavors and contribute to the loss of impartial lipids in the course of neutralization [9]. In additionally, phospholipids are naturally exists as emulsifiers, which bind oil molecules collectively leading to extended viscosity and refining [10]. There are three main processes involved during chemical refining such as neutralization, bleaching, and deodorization. During alkali neutralization process most of the free fatty acids are removed. On the other hand during physical refining, free fatty acids are removed through deodorization process instead of alkali neutralization [11]. Even though both physical and chemical refining processes are efficient to keep up the quality of oil, but in these processes some nutritionally valuable components are also drive out from the oil as well [12].

This research study is aimed to check the impact on the commercial refining of sunflower oil such as crude, neutralization, bleaching and deodorization on some specific physicochemical attributes that are essential for good health. To the best of our expertise no any research work has been mentioned to date on the physicochemical parameters of sunflower oil during industrial processing.

\section{Materials and Methods}

\section{Reagents and oil samples collection}

All the chemicals and reagents used in the present research work were purchased from E-Merck (Dermastd, Germany). Sunflower oil samples (crude, neutralized, bleached and deodorized) were collected from the processing line unit from industrial oil company located at Hyderabad, Pakistan. Collected samples were stored at $4^{\circ} \mathrm{C}$ in amber colored bottles and purged with nitrogen gas stream to decrease the oxidation of oil.

\section{Physicochemical parameters}

Physicochemical parameters of industrially refined sunflower oils were measured according to standard American Oil Chemists Society (AOCS) methods [13]. For instance, 
moisture, color, freezing point ${ }^{\circ} \mathrm{C}$, smoke point ${ }^{\circ} \mathrm{C}$, refractive index $\left(40^{\circ} \mathrm{C}\right)$, free fatty acids, saponification value, iodine value, peroxide value and fatty acids composition.

\section{Moisture}

Moisture content within the processing steps of sunflower oil was checked through oven standard method at $105^{\circ} \mathrm{C} \pm 1^{\circ} \mathrm{C}$ for 1 hour using Moisture Analyzer MX-50 (SHS) Super Hybrid Sensor by using AOCS method Da 2a-48 [13].

\section{Color}

The color of industrially processed sunflower oil was determined by Lovibond Tintometer (Model F) according to AOCS method Cc 13a-43 [13]. Before checking of color, glass cell (1 inch and $5 \frac{1 / 4}{\mathrm{inch}}$ ) was cleaned and dried. The color was matched by different colors of sliding yellow, red and blue color till an excellent match was obtained.

\section{Freezing and smoke point}

For freezing point, about $50 \mathrm{~g}$ of oil sample was taken and kept for half an hour at 2 to $3^{\circ} \mathrm{C}$ in the refrigerator using Cc 9a-47 AOCS method [13]. While, smoke point was measured by using AOCS Cc 9a-48 method [13]. In brief $50 \mathrm{~mL}$ of oil was kept at above $175^{\circ} \mathrm{C}$ for 1 hour on heating mental.

\section{Refractive Index}

The refractive index is the ratio of the speed of light within the substance to the speed of light in a vacuum. The refraction index of sunflower oil at $40^{\circ} \mathrm{C} \pm 1$ was carried out by AOCS Cc-7-25 method [13], and use of the Refractometer.

\section{Free fatty acid}

Free fatty acid in refined steps of sunflower oil was determined as reported in the AOCS method Da 14-48 [13]. In detail oil was solublized in warm neutralized ethyl alcohol and vigorously shaken. The mixture solution was titrated with $0.1 \mathrm{~N}$ sodium hydroxide with the presence of phenolphthalein (indicator).

\section{Saponification value}

Approximately $2 \mathrm{~g}$ of oil was weighed in a round bottom flask and added $25 \mathrm{~mL}$ of alcoholic potassium hydroxide. The material was refluxed for one hour till reaction completed. Following cooling of mixture, $1 \mathrm{~mL}$ of phenolphthalein indicator was poured to it and titrated with $0.5 \mathrm{~N}$ of hydrochloric acid till end point showed with the disappearance of pink color. Likewise, a blank test in same manner was also carried except of adding oil as reported in the AOCS method Da 16-48 [13].

\section{Iodine value}

According to procedure approximately $0.1 \mathrm{~g}$ of oil was taken in the flask and added carbon tetrachloride $(7.5 \mathrm{~mL})$ and Wijis reagent $(12.5 \mathrm{~mL})$ to dissolve oil. The mixture of solution was shaken vigorously and placed for 1 hour in the dark. Later on added $75 \mathrm{~mL}$ 
water and $7.5 \mathrm{~mL}$ fresh solution of potassium iodide and starch indicator. The iodine was liberated from sample mixture and titrated against standard sodium thiosulphate $(0.1 \mathrm{~N})$ solutions till the blue color was disappeared at end point. In the same way, a blank test was also carried out with in the absence of oil using AOCS Cd Ib-87, method [13].

\section{Peroxide value}

Around $2 \mathrm{~g}$ of oil was weighed in conical flask and added chloroform $(10 \mathrm{~mL})$. The content in the flask was shaken vigorously. Then $0.5 \mathrm{~mL}$ of potassium iodide and $15 \mathrm{~mL}$ of glacial acetic acid was mixed and stirred for a minute, in the end solution was kept for 5 minute in dark. Flask was removed from the dark place and added $(75 \mathrm{~mL})$ water along with 2 to 3 drops of starch indicator. The content was titrated against sodium thiosulphate $(0.01 \mathrm{~N})$. Likewise, a blank test was also carried out exception of the oil by Cd 8- 53 AOCS method [13].

\section{Soap content}

About $10 \mathrm{~g}$ of oil in conical flask was weighed, added acetone $(10 \mathrm{~mL})$ and bromophenol indicator 3 drops. The sample mixture was titrated with hydrochloric acid $(0.01 \mathrm{~N})$ until reddish green color altered to yellow color and soap contents were measured by the formula as mentioned in AOCS method Cc 17-95 [13].

\section{Fatty acid composition analysis}

Fatty acid methyl esters (FAMEs) were prepared by using standard IUPAC 2.301 method [14]. Analysis of FAMEs was carried out by the gas chromatography instrument coupled with selective mass detector (GC-MS) model $6890 \mathrm{~N}$ from Agilent equipment. The chromatographic peaks were analyzed by using the ChemStation 6890 Scale Mode software. For the separation of fatty acids A capillary column HP-5MS (5\% phenyl methylsiloxane) ( $30 \mathrm{~m} \times 0.25 \mathrm{~mm}$ ID x $0.25 \mu \mathrm{m}$ film thickness) was used. The oven initial temperature was $150^{\circ} \mathrm{C}$; it was held for 2 min then increased to $230^{\circ} \mathrm{C}$ with $4^{\circ} \mathrm{C} / \mathrm{min}$ of ramp rate. Helium gas was used as the carrier gas with a flow rate of $0.8 \mathrm{~mL} / \mathrm{min}$. Temperature was set at $240^{\circ} \mathrm{C}$ and $260^{\circ} \mathrm{C}$ for injector and detector temperature. $1 \mu \mathrm{L}$ of FAME was injected in the $(50: 1)$ split mode ratio. All analysis was carried out triplicate.

\section{Statistical analysis}

The samples of sunflower oil were analyzed in triplicate. Data were reported as means \pm Standard deviation $(\mathrm{n}=3 \times 3)$.

\section{Results and discussion}

\section{Physical parameters of industrially refined sunflower oil}

The physical parameters of sunflower oil samples were checked including crude, neutralized, bleached and deodorized collected from the vegetable oil factory located at Hyderabad, Pakistan. After each processing stage the results of moisture, color, freezing point, smoke point and refractive index are shown in Table 1. 
Physical properties of crude and industrial processed sunflower oils

Table 1

\begin{tabular}{|l|c|c|c|c|}
\hline \multicolumn{1}{|c|}{ Parameters } & Crude SFO & $\begin{array}{c}\text { Neutralized } \\
\text { SFO }\end{array}$ & $\begin{array}{c}\text { Bleached } \\
\text { SFO }\end{array}$ & $\begin{array}{c}\text { Deodorized } \\
\text { SFO }\end{array}$ \\
\hline Moisture, \% & $0.46 \pm 0.03$ & $0.27 \pm 0.05$ & $0.05 \pm 0.09$ & $0.04 \pm 0.07$ \\
\hline $\begin{array}{l}\text { Color } \\
\text { Red units } \\
\text { Yellow units }\end{array}$ & $\begin{array}{c}2.8 \pm 0.19 \mathrm{R} \\
28.0 \pm 0.21 \mathrm{Y}\end{array}$ & $\begin{array}{c}2.0 \pm 0.22 \mathrm{R} \\
20.0 \pm 0.25 \mathrm{Y}\end{array}$ & $\begin{array}{c}1.6 \pm 0.19 \mathrm{R} \\
16.0 \pm 0.17 \mathrm{Y}\end{array}$ & $\begin{array}{c}1.1 \pm 0.74 \mathrm{R} \\
11.0 \pm 0.71 \mathrm{Y}\end{array}$ \\
\hline $\begin{array}{l}\text { Freezing point, } \\
{ }^{\circ} \mathrm{C}\end{array}$ & $3.2 \pm 0.05$ & $3.0 \pm 0.66$ & $2.8 \pm 0.67$ & $2.3 \pm 0.69$ \\
\hline $\begin{array}{l}\text { Smoke point, } \\
{ }^{\circ} \mathrm{C}\end{array}$ & $226 \pm 0.87$ & $223 \pm 0.95$ & $221 \pm 0.89$ & $219 \pm 0.99$ \\
\hline $\begin{array}{l}\text { Refractive index, } \\
40{ }^{\circ} \mathrm{C}\end{array}$ & $1.4744 \pm 0.0016$ & $1.4745 \pm 0.0018$ & $1.4746 \pm 0.0019$ & $1.4747 \pm 0.0021$ \\
\hline
\end{tabular}

\section{Moisture}

It is widely recognized fact that oil free from moisture has benefit due to the oxidative stability, while the lower storability and suitability owing to higher moisture content of oil for an extended period preservation. During process of neutralization, moisture in crude sunflower oil was reduced from 0.4 to $0.27 \%$ with the level of $41.30 \%$. Within the stage of bleaching, moisture was similarly decreased from 0.27 to $0.05 \%$ from the level of $81.48 \%$. Whereas, deodorization step reduced the moisture percentage of bleached oil from 0.05 to $0.04 \%$ with $20 \%$ reduction efficiency. Generally, the reduction performance of moisture level of neutralization, bleaching and deodorization was determined to be 18.6, 40.2 and $41.2 \%$, respectively.

\section{Color}

Some pigments are accountable for the color of the oil such as carotenoids and chlorophyll. The color of oil distinguished in terms of red (R) and yellow (Y) units. Usually color of crude oil is evaluated in 1 inch cell, while color of bleached and deodorized oil is measured in 5.25 inch cell. The color significantly decreased from 2.8 to $2.0 \mathrm{R}$ and 28.0 to $20.0 \mathrm{Y}$ during alkali neutralization process, which showed that around $28.6 \%$ color loss in both units. In bleaching step, color changed from 2.0 to $1.6 \mathrm{R}$ and 20.0 to $16.0 \mathrm{Y}$, which illustrated $20.0 \%$ color elimination during bleaching. Whereas the oil color again reduced in deodorization process from 1.6 to $1.1 \mathrm{R}$ and 16.0 to $11.0 \mathrm{Y}$, which indicated $31.2 \%$ decrease in color. Overall results of industrial process on neutralization, bleaching and deodorization was established to be $21.65 \% \mathrm{R}, 21.65 \% \mathrm{Y}, 32.42 \% \mathrm{R}, 32.42 \% \mathrm{Y}$ and 45.93 $\% \mathrm{R}, 45.93 \% \mathrm{Y}$, respectively. Color intensity of vegetable oils, mostly eliminated through bleaching and deodorization step. The light color intensity is accepted for vegetable oils to be highly attractive from marketable view-point [15].

\section{Freezing point}

Triglycerides and waxes with saturated fatty acids resist flowing oil smoothly due to sediment. Consequently it is a key sign to determine the freezing point. During sunflower oil processing, it was experimental observation that in neutralization, bleaching and 
deodorization steps freezing point of crude oil reduced from 3.2 to $30{ }^{\circ} \mathrm{C}(6.25 \%), 30$ to $2.8^{\circ} \mathrm{C}(6.66 \%)$ and 2.8 to $2.3{ }^{\circ} \mathrm{C} 17.85 \%$, respectively. Overall input of neutralization, bleaching and deodorization was determined to be $13.33,26.67$ and $60 \%$, respectively, which obviously indentified that deodorization has high impact on freezing point.

\section{Smoke point}

Basically it could be described as the temperature at which oil produces thin stream continuously of the smoke by heating. Smoke point of oil characterizes suitability for frying point of view. During industrial refining, it was observed that smoke point of crude oil was reduced from 226 to $223^{\circ} \mathrm{C}$ for neutralization, 223 to $221^{\circ} \mathrm{C}$ for bleaching and 221 to $219^{\circ} \mathrm{C}$ in deodorization steps. Overall impact of neutralization, bleaching and deodorization was found to be $19.8,32.9$ and $47.3 \%$, respectively.

\section{Refractive index}

The refractive index relies on the fatty acid composition and triglyceride of fat and oil. During all stages of the refining little impact was noticed. Small variation was observed from crude to neutralization and bleaching to deodorization from 1.4744 to $1.4745,1.4746$ to 1.4747 , respectively. Overall influence on refractive index is shown in the percentage from $0.0067,0.0135$ and $0.0203 \%$, respectively for neutralization, bleaching and deodorization.

\section{Chemical parameters of industrially processed sunflower oil}

Chemical parameters are very crucial for the quality parameters of oil. These parameters are mainly important for the edible and health point of view as well as for industrial purposes. Some different chemical parameters of SFO were measured during industrial refining processes as indicated in Table 2. These parameters which include free fatty acid, saponification value, iodine value, peroxide value and soap content.

Table 2

Chemical properties of crude and industrial processed sunflower oil

\begin{tabular}{|l|c|c|c|c|}
\hline \multicolumn{1}{|c|}{ Parameters } & Crude SFO & $\begin{array}{c}\text { Neutralized } \\
\text { SFO }\end{array}$ & $\begin{array}{c}\text { Bleached } \\
\text { SFO }\end{array}$ & $\begin{array}{c}\text { Deodorized } \\
\text { SFO }\end{array}$ \\
\hline Free Fatty Acids, \% & $0.56 \pm 0.09$ & $0.14 \pm 0.06$ & $0.19 \pm 0.07$ & $0.06 \pm 0.03$ \\
\hline $\begin{array}{l}\text { Saponification value, } \\
\text { mg KOH/g of oil }\end{array}$ & $178.5 \pm 0.78$ & $178.2 \pm 0.78$ & $177.5 \pm 0.84$ & $177.2 \pm 0.73$ \\
\hline $\begin{array}{l}\text { Iodine Value, } \\
\text { ( } \mathrm{gI}_{2} / 100 \text { g of oil) }\end{array}$ & $126.0 \pm 0.61$ & $125.8 \pm 0.66$ & $125.5 \pm 0.72$ & $125.2 \pm 0.71$ \\
\hline $\begin{array}{l}\text { Peroxide value, } \\
\mathrm{mEqO}_{2} / \mathrm{kg} \text { of oil }\end{array}$ & $3.2 \pm 0.46$ & $2.9 \pm 0.54$ & $2.3 \pm 0.44$ & $0.9 \pm 0.33$ \\
\hline Soap Content, ppm & - & $121.0 \pm 0.88$ & $60.8 \pm 0.99$ & $30.4 \pm 0.84$ \\
\hline
\end{tabular}




\section{- Food Technology -}

\section{Free fatty acids (FFA)}

This parameter is very significant indicator to determine the suitability and edibility of oils. These fatty acids are not bound chemically to glycerol molecules and are recognized as FFA. The taste odor, and oxidative stability of oil negatively affected by increased FFA. During chemical or physical refining the high FFA contents in edible oil are removed [8]. During all refining steps, noticeable variation in the decrease of FFA was determined in neutralization, bleaching and deodorization steps. However, FFA in crude sunflower oil showed variation from 0.56 to $0.14 \%(75.0 \%)$ for neutralization stage, 0.14 to $0.19 \%$ (35.7\%) for bleaching stage and 0.19 to $0.06 \%$ (68.4\%) in deodorization stage. The effect on FFA during industrial refining stages has approximately $32.58,28.68$ and $38.74 \%$ share reduction for neutralization, bleaching and deodorization, respectively.

\section{Saponification value (SV)}

The SV relies on the fatty acids (types) exists in the oil. Significance of this value is more essential for the production of soap. Through industrial processing the negligible impact on SV was determined from neutralization to deodorization process. SV increased slightly from crude to neutralized oil 178.5 to $178.2 \mathrm{mgKOH} / \mathrm{g}$. While reducing trend of SV was observed in bleaching and deodorization process 178.2 to $177.2 \mathrm{mgKOH} / \mathrm{g}$ and 177.5 to $177.2 \mathrm{mgKOH} / \mathrm{g}$, respectively. The overall influence of refining stages was observed to be $11.72 \%, 38.63 \%$ and $49.65 \%$ for neutralization, bleaching and deodorization.

\section{Iodine value (IV)}

The IV explains the degree of unsaturation of fat and oil. It is recognized fact that least unsaturated oil shows lower iodine numbers, whereas reverse is true for highly unsaturated oil. The IV expressed the classification of oil as non-drying and drying oils. No any major influence was observed during refining stages. There was minor change noticed in IV from neutralization to deodorization 126.0 to $125.8 \mathrm{gI}_{2} / 100 \mathrm{~g}, 125.8$ to $125.5 \mathrm{gI}_{2} / 100 \mathrm{~g}$ and 125.5 to $125.2 \mathrm{gI}_{2} / 100 \mathrm{~g}$. Overall contribution of neutralization, bleaching and deodorization was observed to be $12.83,33.33$ and $53.84 \%$, respectively.

\section{Peroxide value (PV)}

The degree of oil and fat oxidation is determined by the quantity of peroxides present. These are the primary compounds formed during the oxidation of unsaturated fatty acids, which may react further to form the compounds that can cause rancidity $[16,17]$. In the neutralization stage there was no any major influence observed on PV. On the other side comparative study showed somehow positive outcome on PV among neutralization, bleaching and deodorization stages [18]. During the step of bleaching to deodorization, PV was decreased from 2.3 to $0.9 \mathrm{mEqO}_{2} / \mathrm{Kg}$. Overall the effect of industrial refining processes showed the removal of PV by following order 8.56, 25.71 and $65.72 \%$ neutralization, bleaching and deodorization, respectively. 


\section{Soap content (SC)}

Salt of fatty acids in vegetable oil is known as soap content. Shelf life and stability is depends on the presence of soap content in the oil. It is well known fact that, lower the soap content higher the shelf life. Soap content was observed in the neutralization step (121.0 ppm). On the other side reducing trend of soap content was determined in the bleaching (121.0 to 60.8ppm) and deodorization (60.8 to $30.4 \mathrm{ppm}$ ) steps. The processing efficiency on soap content showed following trend from $121 \%, 49.75 \%$ and $50 \%$, respectively in the neutralization, bleaching and deodorization. Overall the input of each industrial refining step such as neutralization, bleaching and deodorization was observed 57.02, 28.65 and $14.33 \%$, respectively.

\section{Fatty acid composition (FAC)}

FAC of sunflower oil samples in all industrial processing steps including crude are indicated in Table 3.

Fatty acid composition of crude and industrially processed sunflower oil

Table 3

\begin{tabular}{|l|c|c|c|c|}
\hline \multicolumn{1}{|c|}{ Fatty Acids (\%) } & Crude SFO & $\begin{array}{c}\text { Neutralized } \\
\text { SFO }\end{array}$ & $\begin{array}{c}\text { Bleached } \\
\text { SFO }\end{array}$ & $\begin{array}{c}\text { Deodorized } \\
\text { SFO }\end{array}$ \\
\hline Myristic (C14:0) & $0.52 \pm 0.02$ & $0.48 \pm 0.01$ & $0.46 \pm 0.06$ & $0.45 \pm 0.07$ \\
\hline Palmitic acid (C16:0) & $5.31 \pm 0.66$ & $4.95 \pm 0.77$ & $4.94 \pm 0.72$ & $4.23 \pm 0.68$ \\
\hline $\begin{array}{l}\text { Palmitoleic acid } \\
\text { (C16:1) }\end{array}$ & $0.92 \pm 0.05$ & $0.85 \pm 0.08$ & $0.84 \pm 0.03$ & $0.82 \pm 0.04$ \\
\hline Stearic acid (C18:0) & $5.12 \pm 0.20$ & $4.75 \pm 0.25$ & $4.57 \pm 0.27$ & $4.42 \pm 0.22$ \\
\hline Oleic acid (C18:1) & $45.08 \pm 0.56$ & $46.48 \pm 0.68$ & $46.62 \pm 0.88$ & $46.58 \pm 0.62$ \\
\hline Linoleic acid (C18:2) & $42.33 \pm 0.66$ & $42.39 \pm 0.63$ & $42.85 \pm 0.77$ & $43.99 \pm 0.75$ \\
\hline $\begin{array}{l}\text { Total saturated } \\
\text { fatty acids }\end{array}$ & 10.94 & 10.18 & 9.97 & 9.09 \\
\hline $\begin{array}{l}\text { Total unsaturated } \\
\text { fatty acids }\end{array}$ & 89.06 & 89.82 & 90.03 & 90.91 \\
\hline
\end{tabular}

There are six different kinds of fatty acids were determined in crude sunflower oil as shown in Figure 1. The total saturated fatty acids and unsaturated fatty acids in the last stage of refining accounted for sunflower oil as $90.91 \%$ and $9.09 \%$, respectively. The highest concentration of fatty acid in sunflower oil was found linoleic acid (C18:2) following by the oleic acid (C18:1), palmitic acid (C16:0), stearic acid (C18:0), palmitoleic acid (C16:1) and myristic acid (C14:0). The poly unsaturated fatty acids are significant fatty acids in vegetable oil, and also better liable to the oxidative rancidity [19]. The results of fatty acids showed that industrial refining treatment steps has no major impact [20], excluding some minor change in the relative proportion of fatty acids. 


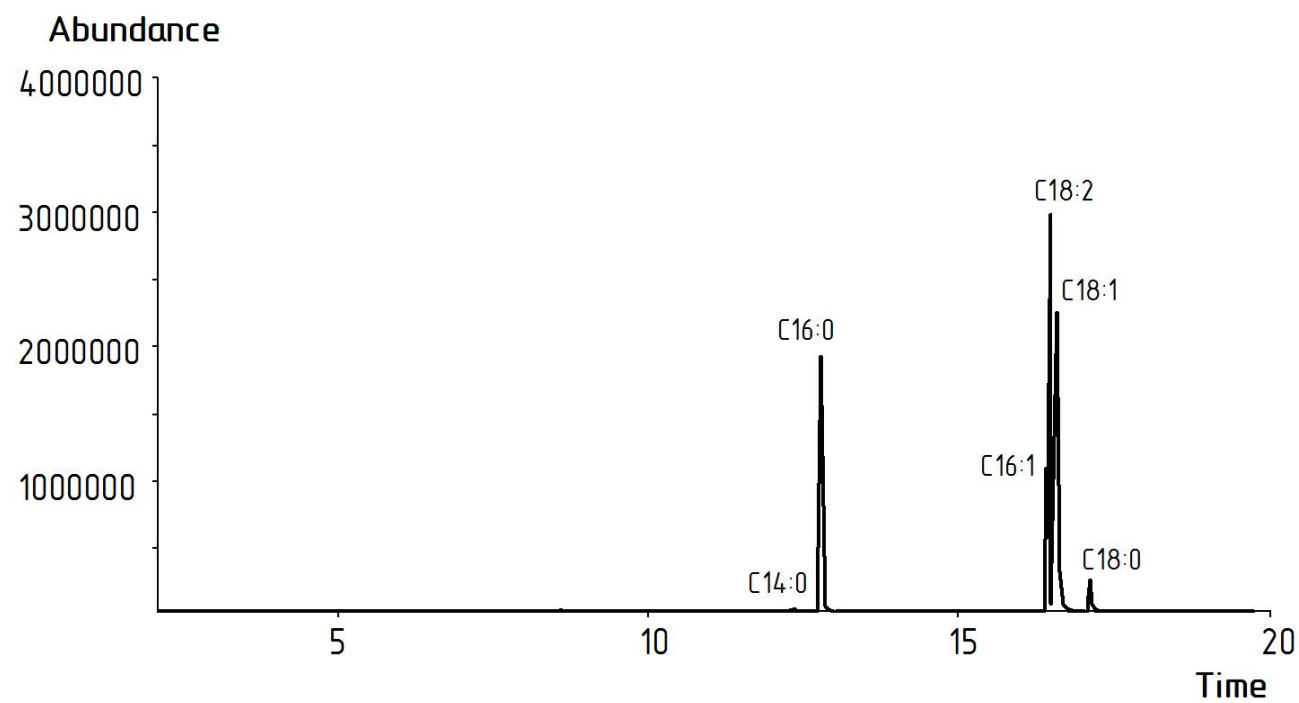

Figure 1. Fatty acid (GC-MS) chromatogram of sunflower oil

\section{Conclusions}

Commercial refining has showed major impact on some quality attributes of SFO. Among four different processing stages, the highly influenced change (reduction) was noticed in color, smoke point, soap content and peroxide value through neutralization, bleaching and deodorization. Whereas, considerable influence was observed on freezing point, smoke point, refractive index, free fatty acid, saponification value and iodine value. On the other hand negligible impact on the fatty acid composition was seen during refining of SFO. From this study, it could be conclude that among different refining stages deodorization step has greater influence on physicochemical attributes on the quality and stability of processed SFO.

\footnotetext{
Acknowledgment. Authors are thankful to National Centre of Excellence in Analytical Chemistry (NCEAC), University of Sindh for granting financial support to carry out this work. Authors are also grateful to Pakistan edible oil factory Hyderabad, Pakistan for providing industrially processes sunflower oil samples.
}

\section{References}

1. Sergio G P., Vereijken J M. (2007), Sunflower proteins: overview of their physicochemical, structural and functional properties, Journal of the Science of Food and Agriculture, 87(12), pp. 2173-2191.

2. Ata-U-Rehman, Anjum F M., Zahoor T., Tahira R. (2006), Evaluation of commercial and laboratory refined sunflower Oils for different food frying, Pakistan Journal of Life and Social Sciences, 4(1-2), pp. 1-7. 
3. Fine Li Y., Fabiano-Tixier F., Abert-Vian A S., Carre M., Pages P., Chemat X F. (2014), Evaluation of alternative solvents for improvement of oil extraction from rapeseeds, Comptes Rendus Chimie, 17(3), pp. 242-251.

4. FAOSTAT data. (2007), Agriculture, Available at: http://faostat.fao.org.

5. Evrard J., Pages X P X., Argenson C., Morin O. (2007), Procédéd'obtention et compositions nutritionnelles deshuiles detournesol, olive et colza, Cahiers de Nutrition et de Diététique, 42(1), pp. 13-23.

6. Combe N., Rossignol-Castera A. (2010), Vegetable oils and frying, Cahiers de Nutrition et Diététique, 45(6S1), pp. 44-51.

7. Medina-Juarez L A., Gamez M N., Ortega G J., Noriega R J A., Angulo G O. (2000), Trans fatty acid composition and tocopherol content in vegetable oils produced in Mexico, Journal of American Oil Chemists Society, 77(7), pp. 721-724.

8. Aluyor E., Aluyor P., Ozigagu C. (2009), Effect of refining on the quality and composition of groundnut oil, African Journal of Food Science, 3(8), pp 201-205.

9. Jiang X., Chang M., Jin Q., Wang X. (2015), Application of phospholipase A1 and phospholipase $\mathrm{C}$ in the degumming process of different kinds of crude oils, Process Biochemistry, 50(3), pp. 432-437.

10. Iwuoha C I., Ubbaonu C N., Ugwo R C., Okereke N U. (1996), Chemical and physical characteristics of palm, palm kernel and groundnut oils as affected by degumming, Food Chemistry, 55(1), pp. 29-34.

11. Alpaslan M., Tepe S., Simsek O. (2001), Effect of refining processes on the total and individual tocopherol content in sunflower oil, International Journal of Food Science and Technology, 36(7), pp. 737-739.

12. Gogolewski M., Nogala-Kalucka M., Szeliga M. (2000), Changes of the tocopherol and fatty Acid contents in rapeseed oil during refining, European Journal of Lipid Science and Technology, 102(10), pp. 618-623.

13. Firestone D. (2009), Official and Recommended Practices of the American Oil Chemist's Society (AOCS) 6th ed, AOCS Press, Champaign.

14. Paquot C., Hautfenne A. (1987), Standard Methods for the Analysis of Oils, Fats and Derivatives. International Union of Pure and Applied Chemistry (IUPAC). 7th Ed. Blackwell Scientific, London, pp. 347.

15. Mahesar S A., Shah S N., Shirazi S T H., Nizamani S M., Kandhro A A., Chang A S. (2017), Outcome of Refining on the Physicochemical Properties of Cottonseed Oil, Pakistan Journal of Analytical and Environmental Chemistry, 18(2), pp. 105-111.

16. Gomathi R., Anusuya N., Chitravadivu C., Manian S. (2011), Antioxidant activity of lettuce tree (Pisonia morindifolia R. Br.) and tamarind tree (Tamarindus indica L.) and their efficacy in Peanut oil stability, Food Science and Biotechnology, 20(6), pp. 1669-167.

17. Mohdaly A A A., Sarhan M A., Mahmoud A., Ramadan M F., Smetanska I. (2010), Antioxidan Efficacy of potato peels and sugar beet pulp extracts in vegetable oils protection, Food Chemistry, 123(4), pp. 1019-1026.

18. Zacchi P., Eggers R. (2008), High-temperature pre-conditioning of rapeseed: A polyphenolenriched oil and the effect of refining, European Journal of Lipid Science and Technology, 110(2), pp. 111-119.

19. Rajam L., Kumar D S., Sundaresan A. Arumughan C. (2005), A novel process for physically refining rice bran oil through simultaneous degumming and dewaxing, Journal of American Oil Chemists Society, 82(3), pp. 213-220.

20. Karabulut I., Topcu A., Yorulmaz A., Tekin A., Ozay D S. (2005), Effects of the industrial refining process on some properties of hazelnut oil, European Journal of Lipid Science and Technology, 107(7-8), pp. 476-480. 